\title{
THE ADMINISTRATIVE WORLD OF MR. JUSTICE FRANKFURTER
}

BERNARD SCHWARTZ $\dagger$

"ONE of the fascinating new games being played by some law professors and others is to compute the 'box scores' of the votes of justices of the Supreme Court in various important lines of cases." 1 The present article is not intended as an addition to the work of those engaged in this type of "numbers game". However valuable the statistical method may be in providing the empirical data which is needed for clear juristic thinking, it should be obvious that its use as the key to the working of the highest court must be limited. The fallacy in this method lies in its single valued criterion of judgment. The Supreme Court and its members can be judged intelligently only from a many-sided viewpoint-not solely from the standpoint of "for" and "against". 2

The work of the Court in a particular field can, however, often be appraised through the opinions of a single member. This is especially true when the Justice concerned happens to have established an outstanding reputation in the field of inquiry before elevation to the highest bench. He is then bound to be assigned more than his share of opinions to write in cases of importance in that field. Or, if he does not agree with the Court's holding or reasoning in an individual decision, he will be quick to dissent or concur. An analysis of his opinions should therefore give a fair cross-section of the work of the Court in the particular field.

Prior to his appointment as a member of the Supreme Court, Felix Frankfurter was recognized as an outstanding expert in administrative law. It is not often that one who has acquired an academic reputation in a particular field-even one as striking as Professor Frankfurter'sis able to expound from the august and authoritative position of the Supreme Court bench the principles he has worked out as a professorial theorist. But scrutiny of Justice Frankfurter's administrative law opinions can prove to be more than an exercise in theoretical research. He has delivered an opinion in most of the important cases in that field during the past decade. An analysis of his opinions can consequently serve to point up significant recent administrative law developments. In addition, it should enable one to appraise not merely the work of the particular Justice but also that of the Court as a whole in dealing with administrative law problems.

† Assistant Professor of Law, New York University Law School.

1. Note, 36 A.B.A.J. 41 (1950).

2. Id. at 42 . 


\section{AdMinistratrve Poiver}

Foremost in Justice Frankfurter's administrative law opinions is a recognition of the place of the administrative process in modern government. Modern administrative tribunals, he wrote in an oft-quoted passage, are the outgrowth of conditions far different from those which gave rise to the judicial process. "To a large degree they have been a response to the felt need of governmental supervision over economic enterprise - a supervision which could effectively be exercised neither directly through self-executing legislation nor by the judicial process. That this movement was natural and its extension inevitable, was a quarter century ago the opinion of eminent spokesmen of the law." 3

A similar approach is apparent in his summary of the development of the Interstate Commerce Commission. "While the [ICC] had been in existence since 1887 , the enlargement of its powers through the Hepburn Act, in 1906, and the Mann-Elkins Act, in 1910, the establishment of similar agencies in many states .. ., the widespread recognition that these specific instances marked a general movement, made increasingly manifest the place of administrative agencies in enforcing legislative policies and called for accommodation of the duties entrusted to them to our traditional judicial system. This Court 'ascribed' to the findings of the Commission 'the strength due to the judgments of a tribunal appointed by law and informed by experience." " And, in like vein, he has referred to the accomplishments of half a century that have won for the ICC a place in the Supreme Court's esteem not second to that accorded the lower federal courts. ${ }^{5}$

As Justice Frankfurter has pointed out, the attitude taken toward the role of the administrative process is of cardinal significance in determining the approach taken in particular administrative law cases. "I think nothing is more important with reference to every one of the issues . . - - the relation between the administrative and the judiciary, the relation between the administrative and the legislative, what powers may be delegated, what powers should be delegated, what should be the nature and scope of judicial review, what procedure is appropriate within the administrative, . . . - every one of those issues is in the ultimate analysis referable to the attitude you take toward the necessity of the legal development that we call administrative law." 6

In the light of his view of that "necessity", it is only natural that

3. Federal Communications Commission v. Pottsville Brosdeasting Co., 309 U.S. $134,142(1940)$.

4. Rochester Telephone Corp. v. United States, 307 U.S. 125, 137-S (1939). See also Federal Communications Commission v. Pottsville Broadeasting Co., 309 U.S. 134, 142 (1940).

5. Frankfurter, Mr. Justice Cardozo and Public Law, 52 HARv. L. Rev. 440, 457 (1939).

6. Frankfurter, Summation of the Conference, 24 A.B.A.J. 282, 283 (1938). 
Justice Frankfurter should not view jealously exercises of administrative power. To him, judicial and administrative agencies are not to be regarded as rivals. The problem, as he sees it, is not in terms of one of the other seeking to take over the field. Judicial law and executive administration are recognized as complementary, not as competing, elements of social control. "It will bear repeating," reads his opinion in the fourth Morgan case, "that although the administrative process has had a different development and pursues somewhat different ways from those of courts, they are to be deemed collaborative instrumentalities of justice and the appropriate independence of each should be respected by the other." 7

\section{A. DELEGATIONS OF POWER}

Validity.-Justice Frankfurter has not delivered any opinions dealing directly with the validity, of delegations of legislative powers to administrative agencies. It is not, however, difficult to tell where he stands. To his mind, the vast delegation of power to the administrative branch is something that inheres "in the very necessities of our situation." 8 It is not surprising therefore that he has joined with the Court in upholding grants of authority as against claims of violation of the maxim against delegation.

That he would do so was apparent from his writings long before he was appointed to the Court. In 1930, referring to the doctrine of the separation of powers, upon which the maxim against delegation is based, he asserted that the "practical demands of government preclude its doctrinaire application," for "we are dealing with what Madison called a 'political maxim' and not a technical rule of law." " And he went on to mention cases which show that there are necessary areas of interaction among the departments of government. "Functions have been allowed to courts as to which Congress itself might have legislated; matters have been withdrawn from courts and vested in the executive; laws have been sustained which are contingent upon executive judgment on highly complicated facts. By these means Congress has been able to move with freedom in modern fields of legislation, with their great complexity and shifting facts, calling for technical knowledge and skill in administration. Enforcement of a rigid conception of separation of powers would make modern government impossible." 10

Such refusal to invalidate legislation merely because it in form delegates legislative power to administrative authorities is to be expected.

7. United States v. Morgan, 313 U.S. 409, 422 (1941). See, similarly, United States v. Ruzicka, 329 U.S. 287, 295 (1946).

8. Frankfurter, supra note 6 , at 284.

9. Frankfurter, The Public and Its Government 77 (1930).

10. Id. at 78 . 
The approach to the delegation problem has shifted from one of formal application of an inflexible maxim to one of determining whether the legislative grant of power is in fact inordinate. And, with this, the focus of judicial inquiry has centered upon the adequacy of the standards contained in enabling legislation.

Standards. - Under American theory, grants of authority to the executive branch must be limited by prescribed standards. The discretion conferred must not be so wide that it is impossible to discern its limits. There must be an ascertainable legislative intent to which the exercise of the delegated power must conform. To this extent only is there meaning in the maxim against delegation-that delegation must not amount to an abdication of the legislative function.

Recent statutes hence generally make use of broad, general standards rather than prescriptions of detail. It has been felt that if the legislature were required to specify in minute detail the course to be followed by the administrative agency, much of the advantage of delegation would be lost. Justice Frankfurter is in the forefront of those on the bench who have taken a liberal attitude toward this type of standard. This can be seen from his opinions dealing with grants of power under the Communications Act of 1934. ${ }^{11}$

Under that Act, the Federal Communications Commission is given wide authority to regulate radio broadcasting. "The Commission was, however, not left at large in performing this duty. The touchstone provided by Congress was, the 'public interest, convenience, or necessity,' a criterion which 'is as concrete as the complicated factors for judgment in such a field of delegated authority permit." "12 In a field where the subject-matter of regulation is as fluid and dynamic as radio, a detailed prescription of standards could have made effective administration impossible. Congress would have frustrated "the purposes for which the Communications Act of 1934 was brought into being by attempting an itemized catalogue of the specific manifestations of the general problems for the solution of which it was establishing a regulatory agency. That would have stereotyped the powers of the Commission to specific details in regulating a field of enterprise the dominant characteristic of which was the dominant pace of its unfolding." 13

The generality of the phrasing in a statute such as the Communications Act of 1934 does not, in Justice Frankfurter's view, mean that the applicable standards are too vague to canalize administrative discretion effectively. The statutory language is not to be read in a vacuum; a general standard may be given specific form and content when

11. 48 Stat. 1064 (1934), 47 U.S.C.A. \$ 151 (Supp. 1949).

12. National Broadcasting Co. v. United States, 319 U.S. 190, 216 (1943).

13. Id. at 219. Compare Phelps Dodge Corp. v. National Labor Relations Board, 313 U.S. 177, 194 (1941). 
looked at in the light of the statutory scheme and its background. Thus the standard of "public interest" in the Communications Act is not so vague and indefinite as to be unconstitutional. "It is a mistaken assumption that this is a mere general reference to public welfare without any standard to guide determination. The purpose of the Act, the requirements it imposes, and the context of the provision in question show the contrary." 14

Implied powers.- - His belief that administrative agencies must be made adequate instruments for expressing the social policies which they were set up to further, ${ }^{15}$ has led Justice Frankfurter to imply authority beyond that literally conferred by the legislature. Enabling legislation, in his view, should be construed as conferring upon the agency concerned those powers which are necessary and proper to the administration of the act, unless there is an express legislative preclusion of the particular power. This is illustrated by his opinion in Phelps Dodge Corp. v. National Labor Relations Board. ${ }^{16}$ The question at issue was whether section 10 (c) of the Wagner Act, ${ }^{17}$ in giving the NLRB authority to require an employer guilty of unfair labor practices to desist and to take such affirmative action "including reinstatement of employees with or without back pay" as will effectuate the policies of the Act, was to be construed as limiting the affirmative power of the Board to ordering the reinstatement of employees.

Justice Frankfurter held that the grant of authority under section 10 (c) included the power to require any affirmative action which might be necessary to effectuate the policies of the Labor Act. "Attainment of a great national policy through expert administration in collaboration with limited judicial review must not be confined within narrow canons for equitable relief deemed suitable . . . in ordinary private controversies." 18 The power conferred was not to be limited to the illustrative case of reinstatement of employees which is given in section 10 (c). "To attribute such a function to the participial phrase introduced by 'including' is to shrivel a versatile principle to an illustrative application. We find no justification for attributing to Congress such a casuistic withdrawal of the authority which, but for the illustration, it clearly has given the Board." 19

A similar approach is apparent in National Broadcasting Co. v.

14. National Broadcasting Co. v. United States, 319 U.S. 190, 226, quoting Hughes, C.J., in New York Cent. Securities Corp. v. United States, 287 U.S. 12, 24 (1932). For a more recent illustration of Justice Frankfurter's attitude, see Secretary of Agriculture v. Central Roig Refining Co., 338 U.S. 604, 611-12 (1950).

15. Frankfurter, The Public and Its Governiment 122 (1930).

16. 313 U.S. 177 (1941).

17. 49 StAT. 449 (1935), 29 U.S.C.A. \& 151 (1947).

18. 313 U.S. at 188.

19. Id. at 189. 
United States, ${ }^{20}$ which upheld the Chain Broadcasting Regulations promulgated by the Federal Communications Commission, as against the claim that they were ultra vires the Communications Act. The regulations at issue provided, in general, that no licenses were to be granted to stations or applicants having specified relationships with broadcasting networks. Each regulation was directed at a particular practice found by the Commission to be detrimental to the "public interest." It is clear that the enabling Act did not expressly confer upon the FCC what in effect amounted to regulatory authority over the business methods of licensees. ${ }^{21}$ Yet the majority opinion by Justice Frankfurter refused to restrict the agency to authority expressly delegated. "We would be asserting our personal views regarding the effective utilization of radio were we to deny that the Commission was entitled to find that the large public aims of the Communications Act of 1934 comprehend the considerations which moved the Commission in promulgating the Chain Broadcasting Regulations. True enough, the Act does not explicitly say that the Commission shall have power to deal with network practices found inimical to the public interest. But Congress was acting in a field of regulation which was both new and dynamic. .... In the context of the developing problems to which it was directed, the Act gave the Commission not niggardly but expansive powers." 22

In other words, as Justice Frankfurter sees it, a regulatory enactment wherein Congress recites a broad policy in light of which the specific provisions of the regulatory scheme must be construed gives rise to a very different duty of construction than do statutes defining specific crimes. In the latter situation, there is no background of broad policy to guide a court in its duty of giving the act its easy, most natural meaning. In a regulatory statute like the Communications Act, a particular power derives meaning from the broad policy expressed. ${ }^{23}$ In such cases, the detailed effectuation of the legislative policies must be left to the agency concerned. "In the nature of things Congress could not catalogue all the devices and stratagems for circumventing the policies of the Act. Nor could it define the whole gamut of remedies to effectuate these policies in an infinite variety of specific situations. Congress met these difficulties by leaving the adaptation of means to end to the empiric process of administration." 24

20. 319 U.S. 190 (1943).

21. Justice Mirphy, dissenting, maintained that to uphold the regulation was "gratuitously [to] bestow upon an agency power which Congress has not granted." Id. at 227.

22. Id. at 218-19.

23. Paraphrasing Singer v. United States, 323 U.S. 33S, 352 (1945) (dissenting opinion). Compare Addison v. Holly Hill Fruit Products, 322 U.S. 607, 616-618 (1944), where Justice Frankfurter used a different approach in construing a regulatory statute which did not contain broad prescriptions.

24. Phelps Dodge Corp. v. National Labor Relations Board, 313 U.S. 177, 194 (1941). 
It must be admitted that the above approach toward administrative exercises of delegated powers contains within it certain dangers. Professor Frankfurter was among those who saw this. While emphasizing the need for a liberal view on administrative exercises of delegated authority, he was careful to warn that "the power which must more and more be lodged in administrative experts, like all power, is prone to abuse unless its exercise is properly circumscribed and zealously scrutinized. For we have greatly widened the field of administrative discretion and thus opened the doors to arbitrariness." 26

If Mr. Justice Frankfurter appears on occasion to have lost sight of this caution, it must be remembered that, at least in his early years on the bench, his approach was affected less by the fear of administrative abuse than by that of administrative ineffectiveness. "In this country we have been so anxious to avoid the dangers of having the expert on top that we suffer from a strong reluctance to have him on tap." ${ }^{26}$ And if, before his appointment to the Court, he could assert that the dominant feeling about government was distrust, ${ }^{27}$ he has done his best to replace that feeling with one of confidence. "We must assume that an agency which Congress has trusted is worthy of the trust. ... We must view what the Commission has done with a generous and not a jealous eye." 28

\section{B. PROCEDURE}

In an appraisal of Justice Cardozo's contributions to public law, Professor Frankfurter placed emphasis upon Cardozo's insistence upon those procedural safeguards which give historic basis to due process. "But insistence on procedural regularity was not, for Cardozo, an expression of inhospitality to the process behind the development of administrative law. . . . Cardozo was not imprisoned by the tags and rags of learning, for he was guided by understanding of the circumstances summarized in historic cliches and by philosophic insight into their significance. Thus he never forgot that forms are related to functions; that court procedures not expressive of ultimate liberties are not necessarily norms of universal applicability; that practices of administration may have a momentum of rationality; and that activities of government which are not the immediate province of courts ought not to be circumscribed by formalities historically appropriate to courts." 29

25. Frankfurter, The Public and Its Government 157-8 (1930). Sce, similarly, Frankfurter, The Task of Administrative Law, 75 U. of PA. L. REv. 614, 618 (1927).

26. Frankfurter, The Public and Its Government 161 (1930).

27. Id. at 3 .

28. Federal Communications Commission v. National Broadcasting Co., 319 U.S. 239, 264 (1943) (dissenting opinion). See similarly, Ashbacker Radio Co. v. Federal Communications Commission, 326 U.S. 327, 336 (1945) (dissenting opinion).

29. Frankfurter, supra note 5, at 457-9. 
As is often the case with such writings, they are a mirror more of the views of their author than of their subject. "Unlike courts, which are concerned primarily with the enforcement of private rights," said Justice Frankfurter in the $K O A$ case, " . . . administrative agencies are predominantly concerned with enforcing public rights although private interests may thereby be affected. To no small degree administrative agencies for the enforcement of public rights were established by Congress because more flexible and less traditional procedures were called for than those evolved by the courts. It is therefore essential to the vitality of the administrative process that the procedural powers given to these administrative agencies not be confined within the conventional modes by which business is done in courts." so

It is a corollary to this attitude that Justice Frankfurter's primary emphasis be placed on ensuring that the administrative process is not hampered in developing the flexibility which he feels to be necessary for its effective functioning. The administrative branch, in his view, must be afforded a large measure of autonomy in procedural matters. ${ }^{31}$ It is not for the courts to invalidate agency procedures merely because they differ in certain respects from those followed in the courtroom, for differences in origin and function may preclude the wholesale transplantation of judicial procedures." "To assume that the modes familiar to courts ... are the only permissible modes ... is to read the discretion given to the [agency] to fashion a procedure relevant to the interests for the adjustment of which it was established through the distorting spectacles of what has been found appropriate for courts." 33 Right to be heard.-With the need for procedural autonomy as his starting point, it is not surprising to find Justice Frankfurter seeking in some instances to uphold agencies which appear to have violated the "fundamentals of fair play" that "require that interested parties be afforded an opportunity for hearing." 34 Even in such cases, he would argue, the agency must be given a wide range of choice and the Court should not imply hampering restrictions not imposed by Congress. ${ }^{35}$

30. Federal Communications Commission v. National Broadcasting Co., 319 U.S. 239, 248 (1943) (dissenting opinion). See Rochester Telephone Corp. v. United States, 307 U.S. 125, 138-9 (1939).

31. See Frankfurter \& Hart, The Business of the Supreme Court at October Term, 1932, 47 HARv. L. REv. 245, 282 (1933), where emphasis is placed on the leaving of rules of procedure before administrative tribunals largely to administrative discretion.

32. Federal Communications Commission v. Pottsville Broadeasting Co., 309 U.S. 134,143 (1940).

33. Federal Communications Commission v. National Broadcasting Co., 319 U.S. 239, 264 (1943) (dissenting opinion). See similarly Ashbacker v. United States, 326 U.S. 327,335 (1945) (dissenting opinion).

34. Federal Communications Commission v. Pottsville Broadeasting Co., 309 U.S. $134,143-4$ (1940).

35. Ashbacker Radio Co. v. Federal Communications Commission, 326 U.S. 327, 335 (1945) (dissenting opinion). 
The $K O A$ case ${ }^{36}$ afforded an opportunity for expressing this attitude in dissent. Respondent radio station was licensed to operate at Denver on a certain frequency. Station WHDH, with a license to operate on the same frequency from Boston, but only during the daytime, applied to the Federal Communications Commission for an increase in power and for operation unlimited in time. Respondent petitioned to intervene in this proceeding, but its petition was denied. The Commission, after a hearing in which respondent was permitted to file briefs and present an oral argument amicus curiae, granted the WHDH application. Thereupon respondent appealed, contending that it was entitled as a matter of right to participate in the hearing on the question of the granting of WHDH's application, and that its rights in this respect were not satisfied by permitting it to file a brief and present argument. The majority of the Court agreed with these contentions.

Justice Frankfurter dissented in a strongly worded opinion. ${ }^{37}$ "In my judgment the decision of the Court in this case imposes a hampering restriction upon the functioning of the administrative process. This is the aspect that lends this case importance and leads me to express the reasons for my dissent." 38 The key statutory provision was section 312 (b) of the Communications Act ${ }^{39}$ which, after giving the FCC authority to modify station licenses, went on to provide that "no such order of modification shall become final until the holder of such outstanding license ... shall have been notified in writing of the proposed action and the grounds or reasons therefor and shall have been given reasonable opportunity to show cause why such an order of modification should not issue." The grant of WHDH's application, in the circumstances, necessarily involved the modification of respondent's outstanding license. ${ }^{40}$ The question was thus posed whether Congress intended by section 312 (b) to require a hearing in which the licensee whose interests might be aggrieved was entitled to intervene as a formal party.

Justice Frankfurter was of the view that the section could not be so construed in the absence of express provision for a hearing in the statute. "The requirement of notice and an opportunity to show cause is not the equivalent of the requirement of a "hearing." " 41 One wonders, however, whether Justice Frankfurter, in construing the statute in this manner, is not himself employing the type of formalistic approach which he has so often condemned. "Certainly one who is to be notified

36. Federal Communications Commission v. National Broadeasting Co., 319 U.S. 239 (1943).

37. Id. at 248 . Douglas, J., also dissented.

38. Ibid.

39. 48 Stat. 1086 (1934), 47 U.S.C.A. $\$ 312$ (b) (Supp. 1949).

40. See 319 U.S. at 244.

41. Id. at 263. See also his dissent on a similar point in Ashbacker Radio Co. v. Federal Communications Commission, 326 U.S. 327, 334 (1945). 
of a hearing and to have the right to show cause is not to be considered a stranger to the proceeding but is, by the very provisions of the statute, to be made a party. . . . A licensee cannot show cause unless it is afforded opportunity to participate in the hearing, to offer evidence, and to exercise the other rights of a party." 42

His predilection in favor of administrative procedural autonomy has not, however, led Mr. Justice Frankfurter to overlook the position of private persons in cases directly involving their personal interests. In such cases, safeguarding the fundamentals of fair play is at least as important for him as promoting administrative efficiency. Thus, his dissent in the $K O A$ case, which involved only the property interests of respondent, should be compared with his more recent dissent in United States ex rel. Knauff v. Shaughnessy, ${ }^{43}$ an alien exclusion case. The question there was whether the United States could exclude without hearing, solely upon a finding by the Attorney General that her admission would be prejudicial to the interests of the United States, the alien wife of a World War II veteran. The War Brides Act of $1945^{44}$ provided that such an alien spouse was to be allowed to join her citizen husband "if otherwise admissible under the immigration laws." The issue was whether this phrase indicated a Congressional intent to subject such war brides to the authority given to the President in 194145 to impose additional restrictions and prohibitions on the entry into and departure of persons from the country during the national emergency. ${ }^{46}$ Among the restrictions imposed had been one which provided that an alien might be denied a hearing where the Attorney General determined that the alien was excludable under the regulations on the basis of information of a confidential nature, the disclosure of which would be contrary to the public interest. It was under this that petitioner was excluded without a hearing. As interpreted by the majority of the Court, the relevant statute had authorized such action.

"This is not the way to read such legislation," asserted Mr. Justice Frankfurter, in dissenting from the decision. "It is true also of Acts of Congress that 'The letter killeth.' Legislation should not be read in such a decimating spirit unless the letter of Congress is inexorable. ... [L]aws are not to be read as though every $i$ has to be dotted and every $t$ crossed." 47 Yet this kind of literal approach is precisely that

42. 319 U.S. at 246. One wonders whether the Court has not moved toward Justice Frankfurter's view in the $K O A$ type of case in Federal Communications Commission v. WJR, 337 U.S. 265 (1949), opinion per Rutledge, J.

43. 338 U.S. 537 (1950), opinion per Minton, J.

44. 59 Stat. 659 (1945), 8 U.S.C.A. \$232 (Supp. 1949).

45. 55 StaT. 252 (1941), 22 U.S.C.A. $\$ 223$ (Supp. 1949).

46. The Court held that this provision was still applicable, since "the national emergency has never been terminated." 338 U.S. at 546.

47. Id. at 548. Jackson, J., also dissented, in an opinion joined in by Black and Frankfurter, J.J. 
which Justice Frankfurter himself used in holding that the private party was not entitled to a hearing in the $K O A$ case. In both cases, it should be noted, the private party was seeking to avail himself of a privilege which had been conferred by the legislature. An alien's opportunity of entry into the country, as Justice Frankfurter, himself, conceded, ${ }^{48}$ is just as much a privilege which Congress may grant or withhold as is a radio station license. In the Knauff case, however, a personal interest of the petitioner was involved. In such a case, Justice Frankfurter is not willing to interpret the relevant legislation as authorizing summary administration unless Congress has spoken explicitly. Reversing his approach in the $K O A$ case, he would require that a hearing be afforded in the absence of an express statutory provision for summary action. Even an apparent authorization is to be narrowly construed. For here "the deepest tie that an American soldier could form may be secretly severed on the mere say-so of an official, however well-intentioned. Although five minutes of crossexamination could enable the soldier-husband to dissipate seemingly convincing information affecting the security danger of his wife, that opportunity need not be accorded." 49

Bias.-In two opinions, Justice Frankfurter has dealt with claims of bias in administrative hearing or deciding officers. In the fourth Morgan case, ${ }^{50}$ the charge of bias was based upon a letter written by the deciding official-the Secretary of Agriculture, who had fixed the rates to be charged by respondent market agencies-to the New York Times immediately following the decision in the second Morgan case, ${ }^{61}$ where the Secretary's order in the same proceeding had been upset by the Court for procedural defects. In this letter, the Secretary vigorously criticized that decision. The letter, asserted the market agencies, indicated that the Secretary was biased and could not properly exercise the quasi-judicial functions conferred upon him by the Packers and Stockyards Act.

In the absence of further evidence of bias, Justice Frankfurter had little difficulty in disposing of this claim. "That [the Secretary] not merely held, but expressed, strong views on matters believed by him to have been in issue, did not unfit him for exercising his duty in subsequent proceedings ordered by this Court. ${ }^{52}$ As well might it be argued that the judges below, who had three times heard this case, had disqualifying convictions. In publicly criticizing this Court's opinion

48. Id. at 549 .

49. Id. at 548 .

50. United States v. Morgan, 313 U.S. 409 (1941).

51. Morgan v. United States, 304 U.S. 1 (1938).

52. In his language here, Justice Frankfurter anticipated the decision in Federal Trade Commission v. Cement Institute, 333 U.S. 613 (1948). For an interesting English analogy, see Franklin v. Minister of Town \& Country Planning, [1947] 1 All E.R. 396, 398. 
the Secretary merely indulged in a practice long familiar in the long history of Anglo-American litigation, whereby unsuccessful litigants and lawyers give vent to their disappointment in tavern or press." 33

Justice Frankfurter's opinion in the fourth Morgan case was followed by similar disposition of an allegation of bias on the part of an NLRB trial examiner. In National Labor Relations Board v. Donnelly Garment Co. ${ }^{54}$ proceedings before the NLRB had resulted in a cease and desist order against the employer. Review of this order came before the Circuit Court of Appeals, which found that the employer had been denied a fair hearing in not being allowed to present certain testimony, and remanded the case to the Board. ${ }^{55}$ The NLRB then set the case for a second hearing before the original examiner, whom the employer insisted was biased because of his prior findings against it. The Board denied a motion for a new examiner. The Court of Appeals held that the denial was improper, pointing out the unfairness of trying issues of fact to those who may have prejudged them." The Supreme Court, through Justice Frankfurter, reversed, asserting that the rule applied below was far stricter than the principles governing disqualification in judicial proceedings. "We find no warrant for imposing upon administrative agencies a stiffer rule, whereby examiners would be disentitled to sit because they ruled strongly against a party in the first hearing." 57

The problem involved in the fourth Morgan and Donnelly cases is essentially that of a claimed prejudgment of the issues by an administrative trier of fact. Such prejudgment is normally not enough to disqualify a judge in a court of law. ${ }^{58}$ One may, it is true, disagree with the basis of the judicial rule on the ground that one who has already come to a decision with regard to a particular issue cannot dispose of that issue with that "cold neutrality of an impartial judge" of which Burke speaks. But if, as is clearly the case, it is uniformly held that mere prejudgment does not disqualify in judicial proceedings, there is, in Justice Frankfurter's phrase, no warrant for imposing a stricter standard upon the administrative judge.

Process of decision. - In the Donnelly case, the NLRB order was originally denied enforcement because of the Board's refusal to allow the employer to present certain testimony. On remand, the examiner heard some of the proof rejected in the earlier proceeding, but declined

53. 313 U.S. at 421.

54. 330 U.S. 219 (1947).

55. Donnelly Garment Co. v. National Labor Relations Board, 123 F.2d 215 (Sth Cir. 1941).

56. Id.; 151 F.2d 854, 870 (8th Cir. 1945).

57. 330 U.S. at 236-7.

58. See Schwartz, Disqualification for Bias in the Federal Dislrict Courts, 11 U. of PitT. L. Rev. 415, 419 (1950). 
to hear the rest on the ground that it would be merely cumulative. On review of the Board's second order, the lower court concluded that neither the examiner nor the Board took the new testimony into account in reaching the findings on which the second order was based. Primarily on that basis, the court held that a full hearing was denied. Justice Frankfurter, in reversing, held that this conclusion was wholly unwarranted, in view of the Board's statement in its decision that it had carefully considered "all of the evidence." "It is a grave responsibility," the opinion asserts, "to conclude that in admitting the testimony of the Company's employees, the Board went through a mere pretense of obedience to the Court's direction, and heard the testimony with a deaf ear and a closed mind. In light of the authority with which Congress has endowed the Board, and with due regard to the conscientiousness which we must attribute to another branch of the Government, we cannot reject its explicit avowal that it did take into account evidence which it should have considered unless an examination of the whole record puts its acceptance beyond reason." 59

Justice Frankfurter's refusal in the Donnelly case to go beyond the administrative decision to determine whether the deciding officials had actually considered all of the evidence which had been presented at the hearing follows naturally from his decision in the fourth Morgan case. $^{60}$ In the first Morgan case, ${ }^{61}$ decided a few years before Justice Frankfurter's appointment to the bench, the Court had laid down the rule that an administrative decision is invalid unless the deciding official has considered the evidence and arguments which have been presented by the parties. "That duty [i:e. of decision] cannot be performed by one who has not considered evidence or argument. It is not an impersonal obligation. It is a duty akin to that of a judge. The one who decides must hear." 62

In subsequent proceedings concerning the validity of the rates which had been fixed in the Morgan proceedings, the district court authorized the market agencies to interrogate the Secretary of Agriculture to determine whether he had complied with the "one who decides must hear" principle of the first Morgan case. He was questioned at length regarding the process by which he had reached the conclusions of his order, including the manner and extent of his study of the record and his consultation with subordinates. Justice Frankfurter, in the fourth Morgan case, held that this type of interrogation of a deciding official was improper. "The short of the business is that the Secretary should never have been subjected to this examination. . . . Such an examination of a judge would be destructive of judicial responsibility. . . .

59. 330 U.S. at 229.

60. United States v. Morgan, 313 U.S. 409 (1941).

61. Morgan v. United States, 298 U.S. 468 (1936).

62. Id. at 481 . 
Just as a judge cannot be subjected to such a scrutiny . . . so the integrity of the administrative process must be equally respected." 63

In effect, Justice Frankfurter's holding on this point destroys the efficacy of the principle of the first Morgan case. Unless the private party is permitted to examine the deciding official on his decision process, it is difficult to see how he can possibly prove his claim that the one who decided did not hear. ${ }^{\text {ot }}$ There are, however, strong considerations on the other side. It has been argued that if the Secretary "were to give to every order which he signs the consideration which the [first] Mrorgan case requires, he would probably have to devote all his time to the conduct of matters which must be considered petty from a national viewpoint." ${ }^{65}$ But if the mental processes of the Secretary could be probed in later court proceedings, he would then most certainly not have the time which Mrorgan $I$ requires. Most of his time would be occupied in judicial proceedings to determine whether he had actually complied with the principle of the first MLorgan case.

From a practical point of view, Justice Frankfurter's position in Morgan IV and the Donnelly case thus seems justified. A reviewing court cannot probe the mental processses of an administrative tribunal any more than it can that of a trial court. Its function is to determine whether the evidence in the record supports the agency findings, not to determine whether the agency in fact considered that evidence. "According to an early English judge, 'The devil himself knoweth not the mind of man,' and a modern reviewing court is not much better equipped to lay bare unexposed mental processes." $c 0$

\section{FINDINGS}

Our analysis thus far has indicated that Mr. Justice Frankfurter's recognition of the place of the administrative process has made him not unsympathetic to agency claims based upon the need for effective administration. He has been quick to imply powers which could be considered necessary for the effectuation of legislative policies, and he has urged the desirability of conceding to the administrative branch authority to determine its own procedures, even if they be at variance with those followed by the judicial process. But his very recognition of the administrative role and the need for the delegation of wide authority to enable that role properly to be performed has led him to place increasing emphasis in recent years upon the manner in which administrative power is exercised.

63. 313 U.S. at 422 .

64. See Note, 36 CoL. L. Rev. 1156, 1157 (1936).

65. Feller, Prospectus for the Further Study of Federal Administralize Late, 47 YaLE L.J. 647, 662 (1938).

66. National Labor Relations Board v. Donnelly Garment Co., 330 U.S. 219, 229 (1947). 
Justice Frankfurter's opinions dealing with the need for findings in administrative decisions are of especial significance in this respect. The very complexity of the technical tasks entrusted to administrative agencies requires that they formulate the basis of their determinations. ${ }^{07}$ As early as the Phelps Dodge case, Justice Frankfurter insisted that the "administrative process will best be vindicated by clarity in its exercise." 68 The demand that agencies articulate the rationale of their decisions stems from substantially the same considerations that call for giving reasons in rendering judicial decisions. ${ }^{69}$ Those whose interests are affected have a natural desire to know the reasons which motivated the administrative decision. This must, in fairness, be satisfied. Moreover, in Justice Frankfurter's view, of even greater importance is the fact that articulation of the bases of administrative decision is essential if the courts are to be enabled adequately to perform the review functions which have been delegated to them. "Congress has seen fit to subject to judicial review such orders . . . as the one before us. That the scope of review is narrowly circumscribed is beside the point. For the courts cannot exercise their duty of review unless they are advised of the considerations underlying the action under review. . . . [T] he orderly functioning of the process of review requires that the grounds upon which the administrative agency acted be clearly disclosed and adequately sustained." 70

Justice Frankfurter's approach to the findings problem is perhaps best shown in his dissenting opinion in New York v. United States. ${ }^{71}$ The case involved the validity of an interim order of the Interstate Commerce Commission increasing class rates in the Northeast by 10 per cent and reducing those elsewhere east of the Rockies by 10 per cent, pending formulation of a national uniform classification. The Commission's expressed goal was that of national uniformity of classification, and the railroads had in fact accepted an invitation to take the initiative in preparing such a uniform classification. It seemed probable, however, that at least ten years would be needed for the completion of such classification, and there was, in the meantime, mounting pressure upon the Commission to eliminate the existing difference between the Northeastern and the Southern and Western rate levels. In the face of this pressure, the Commission concluded that pending completion of the uniform classification certain interim readjustments could be made which would seek to reduce the existing rate differences. It was then that it issued the interim order which was in issue..$^{72}$

67. Frankfurter, silpra note 5, at 458 .

68. Phelps Dodge Corp. v. National Labor Relations Board, 313 U.S. 177, 197 (1941).

69. Eastern-Central Assn. v. United States, 321 U.S. 194, 215 (1944) (dissenting opinion).

70. Securities \& Exchange Commission v. Chenery Corp., 318 U.S. 80,94 (1943).

71. 331 U.S. 284 (1947).

72. For a good discussion of the case, see Jaffe, Administrative Findings or the Amer in America, 34 CoRN. L. Q. 473, 481 (1949). 
In dissenting from the Court's decision upholding the order, ${ }^{73}$ Justice Frankfurter stated that he relied principally upon the fact that there were no detailed findings to support the agency action. This was especially true in regard to the raising of the Northeastern rates by a flat 10 per cent, for there was no finding that the existing rates in that area were unreasonable. One feels from Justice Frankfurter's opinion that he fears that the Commission in its order sought a convenient way of eliminating immediately 20 per cent of the existing discrimination against the Southern and Western rates. "The Procrustean bed," he asserts, "is not a symbol of equality. .. . The findings do not reveal how it happened that putting $10 \%$ on and taking $10 \%$ off respectively will beget just the right adjustment." it Justice Frankfurter, it should be noted, is not saying here that there is nothing in the record to support the ICC view. It was to avoid the need for a detailed probing of the record that the requirement of findings was imposed. "It is not conducive to a fair administration of the Interstate Commerce Act, nor is it consonant with the proper discharge of this Court's task, to require us to dig out indications or evidence giving appropriate answer to these issues from a record consisting of nearly 13,000 pages spread over 21 volumes, which led to a report by the Commission of 320 pages." 75

"Administrative experts," Justice Frankfurter concludes, "no doubt have antennae not possessed by courts charged with reviewing their action. And so it may well be that to the expert feel the justifiable correction of an unbalance between [Northeastern] rates and the rates [elsewhere] is a shift of $10 \%$ in the respective rates.- [Northeastern] rates increased $10 \%$ and rates elsewhere decreased 10\%. But courts, charged as they are with the review of the actions of the Commission, ought not to be asked to sustain such a mathematical coincidence as a matter of unillumined faith in the conclusion of the experts." 76

It should not be thought from the foregoing that Mr. Justice Frankfurter has insisted on findings purely for their own sake as a formalistic requirement in every case. That his rationale is no modern revival of the spirit of a Baron Parke 7 is shown by his dissent in Yonkers $v$. United States. ${ }^{78}$ The ICC has statutory power to authorize a railroad to abandon any portion of its line, ${ }^{79}$ but this power does not extend to street, suburban, or interurban electric railways which are not operated as part of a general steam railroad system. The Commission authorized

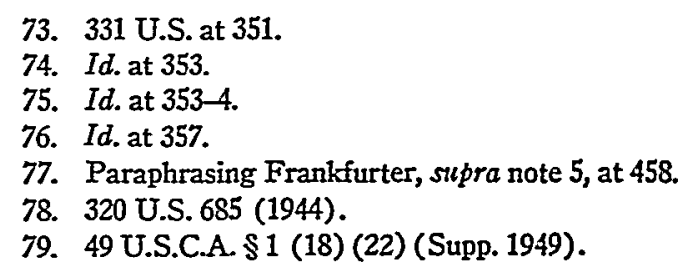


the abandonment of an electric branch line without stating in its order whether the line came within the statutory exception. For that reason the Court held the order invalid; an express finding by the Commission that the line came within the statutory limits was essential to its exercise of jurisdiction, and therefore the absence of such a finding necessitated the setting aside of the order. Justice Frankfurter dissented ${ }^{80} \mathrm{~A}$ jurisdictional finding such as the one involved was implicit in the very taking of action by the agency. The Commission would not have acted if it had not first determined the jurisdictional fact to its satisfaction. "The Commission may very well now formally make such a finding . . ., which in fact is writ large in the Commission's report in granting the application for abandonment, and the weary round of litigation may be repeated to the futile end of having this Court then, forsooth, express an opinion on the merits opposed to that of the Commission and the District Court. This danger if not likelihood of thus marching the king's men up the hill and then marching them down again seems to me a mode of judicial administration to which I cannot yield concurrence." 81

The weight of reason would seem to be with $\mathrm{Mr}$. Justice Frankfurter here. The requirement of findings stems from the need for courts to know what it is that the agency has really determined in order that they may know what to review. ${ }^{82}$ There is surely no lack of such judicial knowledge in the Yorkers case. "Is not insistence on such an empty formalism a reversion to seventeenth century pleading which required talismanic phrases . . . ?" 83

\section{Judicial Power}

If the basic principle in Justice Frankfurter's administrative law philosophy has been his recognition of the place of the administrative process in modern government, of no less importance has been his insistence upon the restricted role of the courts in reviewing agency action. "In endowing this Court with 'judicial power," " he asserted soon after his appointment to the bench, "the Constitution presupposed an historic content for that phrase and relied on assumption by the judiciary of authority only over issues which are appropriate for disposition by judges." 84 In his view, "courts are not charged with general guardianship against all potential mischief in the complicated

80. 320 U.S. at 692 , joined in by Reed and Jackson, J.J.

81. Id. at $693-4$.

82. Id. at 694 .

83. Id. at 698. Other cases showing that Justice Frankfurter's attitude on findings is not unduly rigid are Interstate Commerce Commission v. Mechling, 330 U.S. 567, 583 (1947) (dissenting opinion); Eastern-Central Ass'n v. United States, 321 U.S. 194, 212 (1944) (dissenting opinion).

84. Coleman v. Miller, 307 U.S. 433,460 (1939). 
tasks of government." 85 The judicial function is a more limited one. Judicial power, however large, has an orbit more or less strictly defined. ${ }^{86}$ It "could come into play only in matters that were the traditional concern of the courts at Westminster and only if they arose in ways that to the expert feel of lawyers constituted 'Cases' or 'Controversies.' . . . [E]ven as to the kinds of questions which were the staple of judicial business, it was not for courts to pass upon them as abstract, intellectual problems but only if a concrete, living contest between adversaries called for the arbitrament of law." 87

As Justice Frankfurter sees it, the insistence upon the presence of an actual controversy as a prerequisite to the exercise of judicial power is of fundamental significance. "One of the greatest sources of strength of our law is that it adjudicates concrete cases and does not pronounce principles in the abstract." \&s The business of courts is thus adjudication, not speculation. They are concerned with actual living controversies, and not abstract disputation. ${ }^{\$ 9}$

Emphasizing as he does the importance of judicial self-limitation, Justice Frankfurter has been cautious in his approach to cases presenting problems of judicial review of administrative action. He has constantly urged the need for the courts to deal directly with the particular case and to avoid over-hasty abstractions." "Certainly the recent growth of administrative law counsels against generalizations regarding what is compendiously called judicial review of agency action. And so we deem it desirable, in a case like this, to hug the shore of the precise problem before us in relation to the provisions of the particular Act immediately relevant." 91

Justice Frankfurter's views on this point were well stated in an address delivered in 1938. "I think it is inevitable that you must be

85. Federal Communications Commission v. Pottsville Broadcasting Co., 309 U.S. 134, 146 (1940). Compare Secretary of Agriculture v. Central Roig Refining Co., 338 U.S. 604, 618 (1950).

86. Frankfurter \& Fisher, The Business of the Supreme Court at the October Terms, 1935 and 1936, 51 HARv. L. Rev. 577, 621 (1938).

87. Coleman v. Miller, 307 U.S. 433,460 (1939).

88. New York v. United States, 326 U.S. 572, 575 (1946).

89. Frankfurter \& Fisher, sitpra note 86 . Compare Frankfurter, A Notc on Adzisory Opinions, 37 HARV. L. REv. 1002 (1924). Recent indications of Justice Franlfurter's hostility to judicial abstractions are contained in United States v. Congress of Industrial Organizations, 335 U.S. 106, 124 (1948) (concurring opinion); Central Greyhound Lines v. Mealey, 334 U.S. 653, 655 (1948); Republic Gas Co. v. Ollahoma, 334 U.S. 62, 67 (1948).

90. Compare Larson v. Domestic \& Foreign Corp., 337 U.S. 682, 706 (1949) (dissenting opinion), where Justice Frankfurter recognizes that judicial generalizations are sometimes necessary.

91. United States v. Ruzicka, 329 U.S. 287, 295 (1946). Compare OWlahoma v. Civil Service Commission, 330 U.S. 127, 147 (1947) (concurring opinion), waming against premature construction of the Administrative Procedure Act. 
in an intellectual fog thus far,-I am not saying what may happen eventually, -if you talk about 'judicial review' in the abstract. The English are so hopeful that they think they can do something eventually about the fog of London. Certainly, we are in the fog of 'judicial review.' I think we are in the fog of inadequate experience, we are as yet in a totally inadequate stage for suggesting wholesale remedies or large systems." 92

\section{A. AVAILABILITY OF REVIEW}

Silence of Congress.-With his conception of the judicial function in controlling the other branches of government as a limited one, it is not surprising that Justice Frankfurter has been the least disposed, of all the Justices on the Court, to imply rights of review. ${ }^{93}$ As he sees the problem of the availability of review over administrative action, the judicial authority in particular cases depends upon Congressional delegation of the review power. "When judicial review is available and under what circumstances, are questions . . . that depend upon the particular Congressional enactment under which judicial review is exercised." ${ }^{4}$ It follows from this that unless there is an express statutory provision for review, access to the courts is not available in the particular case.

If, as Justice Frankfurter pointed out in the Scripps-Howard case, the "search for significance in the silence of Congress is too often the pursuit of a mirage," ${ }^{95}$ he himself has on occasion not been averse to engaging in such pursuit. For, in dealing with the question of the availability of review, he has started with the proposition that the silence of Congress indicates an intent to preclude review. "To ascertain whether an order of the Interstate Commerce Commission is open to judicial review, it should rigorously be borne in mind that jurisdiction to review such an order must have been conferred by Congress. To assume that an order of the Commission for which reviewing power is not conferred is presumably reviewable by the courts is to start with the answer of the problem to be solved. Unless Congress has chosen to give the courts oversight of a determination by the Commission, the courts have not the power of oversight where, as here, the Constitution does not require it." 96

92. Frankfurter, Summation of the Conference, 24 A.B.A.J. 282, 285 (1938). Sec, similarly, Frankfurter, The Task of Administrafive Law, 75 U. of PA. L. REv. 614, 61920 (1927).

93. See Jaffe, The Judicial Universe of Mr. Justice Frankfurter, 62 Harv. L. REv. 353, 372 (1949) ; Pritchett, The Roosevelt Court 194 (1948).

94. National Labor Relations Board v. Cheney Lumber Co., 327 U.S. 385, 388 (1946).

95. Scripps-Howard Radio v. Federal Communications Commission, 316 U.S. 4, 11 (1942).

96. United States v. Interstate Commerce Commission, 337 U.S. 426, 449 (1949) (dissenting opinion). On the other hand, where Congress has not been silent, Justice Frank- 
In his constant adherence to this principle, Justice Frankfurter has usually not had the concurrence of a majority of the Court. The case which, perhaps, best illustrates how Justice Frankfurter's approach differs from that of most of the Justices is Stark $v$. Wickard. ${ }^{g 7}$ The Secretary of Agriculture, acting under the Agricultural Marketing Agreement Act of 1937,98 had promulgated an order regulating the marketing of milk in the Greater Boston area. The order provided for fixing minimum prices to be paid to producers, and the prescribed formula authorized a deduction for certain payments to cooperatives. Producers, claiming that promulgation of the deduction provision was beyond the Secretary's statutory power, brought suit in the district court to enjoin him from carrying out the challenged portion of the order. The majority of the Court, through Justice Reed, held that the suit could be maintained even conceding that there was no direct judicial review granted by this statute for these proceedings. ${ }^{.3}$

Justice Frankfurter dissented. ${ }^{100}$ As he saw the case, the majority of the Court was adding to what Congress had written a provision for judicial relief of producers. ${ }^{101}$ But "provision for judicial remedies for ... producers is significantly absent. Such omission is neither inadvertent nor suprising. It would be manifestly incongruous for an Act which provides that no order shall be directed at producers ${ }^{102}$ to give to producers the right to attack the validity of such an order in court. To create a judicial remedy for producers when the statute gave none is to dislocate the Congressional scheme of enforcement." 103

In limiting the availability of review to cases where there are express statutory review provisions, ${ }^{104}$ Justice Frankfurter would seem to

furter has insisted that the courts must exercise the review power conferred. Burford v. Sun Oil Co., 319 U.S. 315, 336 (1943) (dissenting opinion).

97. 321 U.S. 288 (1944).

98. 50 Stat. 246 (1937), 7 U.S.C.A. $\$ 601$ (1939).

99. 321 U.S. at 308.

100. Id. at 311. Black, J., also dissented.

101. Id. at 319 .

102. Under the Act, the price orders of the Secretary were directed only to mill: handlers. But, since it is clear that the order at issue did reduce the amount which the producers received for their product, Justice Frankfurter's emphasis on this point would seem to rely on the form rather than the substance of the order.

103. 321 U.S. at 317. In Switchmen's Union v. National Mfediation Board, 320 U.S. 297 (1943), opinion per Douglas, J., the Court appears to have adopted Justice Frankfurter's approach in Stark v. Wickard. Justice Reed, who had delivered the Stark opinion, dissented. On the other hand, in the more recent case of United States v. Interstate Commerce Commission, 337 U.S. 426, 444 (1949), Justice Frankfurter again found himself in dissent from the Court's holding that review was available in the absence of statutory provisions therefor. See also his concurring opinion in Estep v. United States, 327 U.S. 114, 134 (1946), where he differed from the Court on this point.

104. Justice Frankfurter has applied this principle even in a case involving interests of the person. Ludecke v. Watkins, 335 U.S. 160 (1948), where he spoke for a bare 
be restricting the judicial role unduly. Even in the absence of statutory review provisions, the Anglo-American courts have developed means for controlling administrative action. As stated in a leading English case, an administrative tribunal "is not an autocrat free to act as it pleases, but is an inferior tribunal subject to the jurisdiction which the Court of King's Bench for centuries, and the High Court since the Judicature Acts, has exercised over such tribunals." 106 The mere fact that one starts in a particular case with a statute which makes no provision for judicial review is not decisive. "For the silence of Congress as to judicial review is not necessarily to be construed as a denial of the power of the Federal courts to grant relief in the exercise of the general jurisdiction which Congress has conferred upon them." 106

The review power of the courts in these cases is an inherent one which arises out of the delegation to them of the "judicial power" under the Constitution. "When Congress passes an Act empowering administrative agencies to carry on governmental activities, the power of those agencies is circumscribed by the authority granted. This permits the courts to participate in law enforcement entrusted to administrative bodies only to the extent necessary to protect justiciable individual rights against administrative action fairly beyond the granted powers. The responsibility of determining the limits of statutory grant; of authority in such instances is a judicial function entrusted to the courts by Congress by the statutes establishing courts and marking their jurisdiction." ${ }^{107}$

Yet under Justice Frankfurter's view, in the absence of statutory review provisions, an admin strative order is final and not reviewable by any court even though entered arbitrarily, without substantial supporting evidence, and in defiance of law. "Such a sweeping contention for administrative finality is out of harmony with the general legislative pattern of administrative and judicial relationships." 103 The need for judicial control such as that exercised by the majority of the Court in Stark v. Wickard has been emphasized in strong language by the Court of Appeals for the District of Columbia. "If the judiciary had no power in such matter, the only practical restraint would be the self-restraint of the executive branch. Such a result is foreign to our concept of the division of the powers of government." 209

majority of the Court. The Court there appears to have been influenced by the fact that the authority concerned was vested in the President and related to the field of forcign affairs, as it did in Chicago \& Southern Air Lines v. Waterman S.S. Corp., 333 U.S. 103 (1948), another case of implied preclusion of review.

105. Rex v. Board of Education, [1910] 2 K.B. 165, 178.

106. Estep v. United States, 327 U.S. 114, 120 (1946), per Douglas, J.

107. Stark v. Wickard, 321 U.S. 288, 309-10 (1944).

108. United States v. Interstate Commerce Commission, 337 U.S. 426, 433-4 (1949), per Black, J.

109. Fleming v. Moberly Milk Products Co., 160 F.2d 259, 265 (App.D.C. 1947). 
Reviewable action.-Influenced by his strong feeling that the courts are not charged with the minute supervision of everything done by the administrative branch, Justice Frankfurter has been careful to limit the types of agency action which could be reviewed. His approach to the question of what kinds of agency action are reviewable has not, however, been a formalistic one. His first important administrative law opinion, Rochester Telephone Corp. v. United States, ${ }^{130}$ formulated the principle that the availability of review in a given case does not depend upon the form of the particular agency action. Concurrently, it struck down the so-called "negative order" doctrine, a limitation upon the availability of review which had been based wholly upon the form of administrative action. In Justice Frankfurter's view, a formalistic concept such as that of negative orders has not served to clarify the relations between administrative bodies and the courts, but has rather tended to obscure them. " 'Negative' has really been an obfuscating adjective in that it implied a search for a distinction-non-action as against action-which does not involve the real considerations on which rest ... the reviewability of Commission orders within the framework of its discretionary authority and within the general criteria of justiciability." 111

Whether particular administrative action is reviewable depends upon whether such action is "final." Agency action is clearly not "final" in a given case if the private party has not complied with the rule requiring the exhaustion of administrative remedies. Of course, that rule only applies in cases where there is, in fact, an administrative remedy to exhaust-it presupposes that "administrative remedies as a condition to judicial relief are not rendered futile and nugatory." 112 But if he finds that an administrative remedy is available which has not been pursued, Justice Frankfurter does not hesitate strictly to apply the exhaustion rule. In United States v. Rusicka, ${ }^{113}$ the Government brought suit under the Agricultural Marketing Agreement Act to enforce an order issued by the Secretary of Agriculture requiring

110. 307 U.S. 125 (1939).

111. Id. at 141. His rejection of formalism here has also appeared to influence Justice Frankfurter in his constant opposition to what is still a formidable barrier to access to the courts in some cases-i.e., the doctrine of sovereign immunity. See Larson v. Domestic \& Foreign Corp., 337 U.S. 682, 705 (1949) (dissenting opinion); Kennecott Copper Corp. v. Tax Commission, 327 U.S. 573, 580 (1946) (dissenting opinion); Great Northern Ins. Co. v. Read, 322 U.S. 47, 57 (1944) (dissenting opinion) ; Keifer \& Keifer v. Reconstruction Finance Corp., 306 U.S. 381 (1939).

112. United States v. Blair, 321 U.S. 730, 739 (1944). Justice Franlffurter appears to have lost sight of this principle in his dissent in Order of Railway Conductors v. Swan, 329 U.S. 520, 530 (1947), where he asserted that the exhaustion rule precluded resort to the courts even in a case where a jurisdictional frustration on the administrative level made impossible the effective use of the administrative remedy.

113. 329 U.S. 287 (1946). 
handlers of milk to pay money into a Producer-Settlement Fund. Defendant handlers sought to justify their failure to pay on the ground that the demand was based upon faulty inspection of their accounts and improper tests of their milk and milk products. Under the Act, ${ }^{114}$ defendants could have sought a hearing before the Secretary on their petition to modify or be exempted from the order. If their petition was denied, review could then be had in the federal courts.

Justice Frankfurter held that, since defendants had not taken advantage of the administrative remedy provided by the statute, they could not now assert their objections to the order. It made no difference that this was an enforcement proceeding at the suit of the Government rather than a review action brought by the private party. "It is suggested that Congress did not authorize a district court to enforce an order not 'in accordance with law.' The short answer to this rather dialectic point is that whether such an order is or is not in accordance with law is not a question that brings its own immediate answer, or even an answer which it is the familiar, everyday business of courts to find. Congress has provided a special procedure for ascertaining whether such an order is or is not in accordance with law. . . . Congress has provided that the remedy in the first instance must be sought from the Secretary of Agriculture." 115

To say that administrative remedies must be exhausted does not, however, solve the problems of whether particular agency action is "final" action subject to review. As Justice Frankfurter aptly pointed out in a decision dealing with a related matter, ${ }^{116}$ no self-enforcing formula defining when an order is final can be devised. ${ }^{117}$ One thing is clear in his approach to the problem. If his opinions often appear unduly to restrict the availability of review, he is motivated by what he believes to be the practical necessities of proper judicial administration. "The considerations that determine finality are not abstractions but have reference to very real interests-not merely those of the immediate parties but, more particularly, those that pertain to the smooth functioning of our judicial system." 118

In the Rochester Telephone decision, Justice Frankfurter referred to cases where the agency order did not in itself affect complainant, but only affected his rights adversely on the contingency of future administrative action. "In view of traditional conceptions of federal judicial power," he said, "resort to the courts in these situations is either pre-

114. 7 U.S.C.A. $\$ 608$ (c) (15) (1939).

115. 329 U.S. at 294.

116. Whether a judgment was "final" within the meaning of $\$ 237$ of the Judicial Code (now $\S 1257$ of the Revised Code of 1948).

117. Republic Gas Co. v. Oklahoma, 334 U.S. 62,67 (1948).

118. Id. at 69 . 
mature or wholly beyond their province." 119 Yet, as he has recognized, there have been instances where the courts have entertained review of an order that might otherwise be deemed interlocutory, because the controversy had proceeded to a point where the losing party would be irreparably injured if review were unavailable. ${ }^{120}$

In Columbia Broadcasting System v. Uniled States, ${ }^{121}$ the appellant sought review of the Chain Broadcasting Regulations promulgated by the Federal Communications Commission. The regulations in question provided that no licenses were to be granted to stations or applicants having specified contractual relationships with broadcasting networks. Appellant was a network organization whose business depended upon the maintenance and renewal of contracts such as those against which the instant regulations were directed. It was argued that the order promulgating the regulations was not reviewable, for in and of themselves they did not purport to affect the contract rights of appellant or its affiliate stations. They merely laid down principles to govern future action of the Commission. Their effect was thus contingent upon FCC action in future license application or renewal cases, and it was only when the Commission acted in such a case in conformity to the regulations that its action was reviewable.

This argument was rejected by Mr. Chief Justice Stone, speaking for the majority of the Court, but it was adopted in a lengthy dissenting opinion by Mr. Justice Frankfurter. ${ }^{122}$ "The regulations themselves," he states, "determine no rights. They alter the status of neither the networks nor licensees. As such they require nobody-neither the networks, the licensees, nor the Commission-to do anything. They are merely an announcement to the public of what the Commission intends to do in passing upon future applications for station licenses. . . . It is only after a proceeding has been started . . . and adversely concluded against a party that legal sanctions come into play-the Commission can bring proceedings to enforce its order of revocation and, correspondingly, the licensee can bring suit... challenging the validity of the Commission's termination of the license." 123

One wonders, however, whether Justice Frankfurter's opinion does not lose sight of the realities of the particular factual situation. It is to deal in abstract legal learning rather than the realities of the record ${ }^{124}$ to assert that appellant was not adversely affected by the order promulgating these regulations. Such a claim loses sight of the im-

119. Rochester Telephone Corp. v. United States, 307 U.S. 125, 130 (1939).

120. Republic Gas Co. v. Oklahoma, 334 U.S. 62, 6S (1948).

121. 316 U.S. 407 (1942).

122. Id. at 429, joined in by Reed and Douglas, J.J.

123. Id. at $430-31,437$.

124. Paraphrasing Indianapolis v. Chase National Bank, 314 U.S. 63,69 (1941). 
mediate effect upon appellant's contractual relations with its affiliates. For knowledge that contracts such as those they had with appellant would result in a refusal to renew their station permits, would lead the affiliates to repudiate the contracts rather than run the risk of losing their licenses. "If the regulations are valid they alter the status of appellant's contracts and thus determine their validity in advance of such [renewal] proceedings. By striking them down by a determination proclaimed in advance that licenses shall be cancelled or refused because of a previous failure to comply with the regulations, they impose a penalty and sanction for non-compliance far more drastic than the fines customarily imposed for breach of reviewable administrative orders." 125

Appellant's rights were affected more immediately than by the mere contingency of future administrative action. It is true, as Justice Frankfurter pointed out, that licensees who regarded the regulations as invalid were free to continue their existing contracts and to challenge the regulations when the Commission refused to renew their licenses and that the network could intervene in the renewal proceeding. ${ }^{120}$ But is it not more likely that there would never be such a challenge by a licensee in a renewal proceeding, for to make the challenge would be to chance losing its license? The licensees were "free only in the sense that all those who do not choose to conform to regulations which may be accepted to be lawful are free by their choice to accept the legal consequences of their acts. Failure to comply with the regulations entails such consequences to the station owner and to appellant. These are the loss of the affiliated stations' licenses if they adhere to their contracts, and disruption of appellant's network through the declared unlawfulness of the contracts, if the regulations are valid." 127

Justice Frankfurter has adhered to the views expressed by him in the Columbia Broadcasting case in his more recent opinion in Eccles $v$. People's Bank, ${ }^{128}$ though this time with the concurrence of a majority of the Court. The respondent bank had been granted membership in the Federal Reserve System subject to a condition which provided for withdrawal from membership within 60 days after written notice from the Board of Governors if a named corporation or any of its affiliates thereafter acquired any interest in the bank without the approval of the Board. Respondent claimed that the imposing of this condition was beyond the powers of the Board of Governors and sought a declaratory judgment to that effect.

125. Stone, C.J., in Columbia Broadcasting System v. United States, 316 U.S. 407, 418 (1942).

126. Id. at 445 .

127. Stone, C.J., id. at 419.

128. 333 U.S. 426 (1948). 
Justice Frankfurter, this time speaking for the Court, held that the bank's action was premature; respondent could not in any way be affected by the administrative action at issue before the Board of Governors commenced revocation proceedings for a violation of the condition. "The Bank seeks a declaration of its rights if it should lose its independence or if the Board of Governors should reverse its policy and seek o invoke the condition even though the Bank remains independent. ... The concurrence of these contingent events, necessary for injury to be realized, is too speculative to warrant anticipatory judicial determinations." 129

What has been said above with regard to the Columbia Broadcasling case would appear to apply with equal force to Eccles v. People's Bank. Review should be afforded at this stage under the analysis in Mr. Chief Justice Stone's opinion in Columbia Broadcasting System v. United States "a case where prematurity was clearer than here." 130 "It seems obvious that the requirement was a restriction on the market for respondent's stock and therefore detrimental to the conduct of its business, a continuing threat of the Board to exclude respondent from the benefits of the System."131 It is all very well to argue, as Justice Frankfurter does, that respondent is not actually injured until the Board moves to revoke its membership for a violation of the condition. But, in a practical sense, does not that make it most difficult for respondent to obtain a judicial determination of the vires of the condition? At that later stage, it could only secure that determination at the risk of losing its membership, if the condition were held to be within the Board's authority.

Standing.-Under Justice Frankfurter's approach to the question of the availability of review, the "standing" of a private party to challenge particular administrative act:on is dependent upon whether a statute has given him such standing. The reliance upon statute does not, however, produce an automatic answer in any given case. As pointed out by the Attorney General's Committee on Administrative Procedure, "proposals to define the class of persons who can attack acts of administrative agencies in general are either futile or dangerous: Futile because they can hardly go beyond the present generality of persons 'aggrieved' or 'adversely affected' or otherwise having 'legal standing'; dangerous if they go beyond it, unless the redefinition is based on detailed consideration of the specific judicial determinations made in the particular situation." 132

Most of the statutory provisions concerning standing have conse-

129. Id. at 432 .

130. Reed, J., dissenting, id. at 437. It should be noted that Justice Reed had joined in Justice Frankfurter's dissent in the Columbia Broadcasting case.

131. Id. at 435 .

132. Rep. Atr'y GeN. 85 (1941). 
quently gone no further than to authorize review to be sought by persons "adversely affected" or "aggrieved" by the agency action. These statutory provisions in and of themselves give little aid in determining whether a private party has standing to attack particular administrative action. "Of course, such words as 'aggrieved' and 'adversely affected,' . . . in a statute governing a particular agency, do not provide solutions for problem cases. The solution must be found in broader indications of legislative policies concerning interests to be protected, and, when legislative expression is unclear, in the policy ideas of courts." 133

Mr. Justice Frankfurter has applied such statutory provisions concerning standing strictly against the private party seeking review. This can be illustrated by his dissenting opinion in the $K O A$ case, ${ }^{134}$ which has already been discussed insofar as the right to be heard before the agency is concerned. ${ }^{135}$ It will be recalled that, in that case, respondent station KOA challenged an order of the Federal Communications Commission which granted an application for an increase in power and for operation unlimited in time to a station operating on the same frequency as respondent. The relevant statutory provision ${ }^{130}$ provided for an appeal to the Court of Appeals for the District of Columbia in such cases by an applicant whose application was refused or by "any other person aggrieved or whose interests are adversely affected by any decision of the Commission granting or refusing any such application."

The majority of the Court held that KOA had standing under this provision. "It would be anomalous if one entitled to be heard before the Commission should be denied the right of appeal from an order made without hearing. . . . In view of the fact that $\$ 312$ (b) grants KOA the right to become a party to the proceedings, we think it plain that it is a party aggrieved, or a party whose interests will be adversely affected by the grant of WHDH's application." 137

Justice Frankfurter, dissenting, disagreed with this construction of the standing provision of the Communications Act. "It must not be concluded that anyone who claims to be 'aggrieved' or' who is any way adversely affected by Commission action has a right to appeal." 138 As he read the statute, "KOA had to make a showing that its interests were substantially impaired by a grant of the WHDH application.

133. Davis, Standing to Challenge and to Enforce Administrative Action, $49 \mathrm{Col}$ L. REv. 759, 768 (1949).

134. Federal Communications Commission v. National Broadcasting Co., 319 U.S. 239, 248 (1943).

135. See pages 1236-7 supra.

136. 47 U.S.C.A. $\$ 402$ (b) (Supp. 1949).

137. 319 U.S. at $246-7$, per Roberts, J.

138. Id. at 260 . 
This, the record makes clear, it failed to do. In its notice of appeal to the court below, KOA made only a general allegation ... that the Commission's action resulted in a 'substantial modification' of its license. No supporting allegations of fact were tendered." 159

The holding of the majority of the Court in the $K O A$ case appears to follow logically from its earlier decision in Federal Communicalions Commission v. Sanders Radio Station, ${ }^{140}$ in which Justice Frankfurter had joined. There the Court had held that a licensee who claimed that he would be financially injured by the competition resulting from the grant of a license to another had standing to appeal from an FCC order granting such license. As Professor Davis has pointed out, IKOA's interest in freedom from electrical interference is at least as deserving of protection as Sanders' interest in freedom from economic competition. ${ }^{141}$ Justice Frankfurter's reading of the Sanders opinion as requiring by implication that the licensee had to make a showing that there was probable injury of a "substantial character" 1\$2 may have been due to his fear that any other rule might unduly hamper judicial administration. "So much by way of limitation seems necessary to prevent . . mass appeals by the industry at large, with resulting hopeless clogging of the administrative process by judicial review." 143

This fear seems largely groundless. "The notion that permitting all those with substantial interests to get judicial review will flood the courts with 'hundreds of thousands' of cases was satisfactorily exploded in an opinion of a lower court which pointed out that the first decision will to some extent have a stare decisis effect, and that where United States Courts of Appeals have exclusive jurisdiction to review, the filing of a petition with one court will prevent the other courts from entertaining a similar petition filed by any other person aggrieved." 144

In a situation like that presented in the $K O A$ case, it is most unlikely that the FCC order would have ever been brought before the courts if KOA had not been permitted to challenge it. In a practical sense, then, such administrative action would be placed in a conclusive position, for it would never be challenged by the only other parties involved, the Commission or the successful applicant. In view of the role of the courts in our polity in controlling executive action, it is of the utmost importance that agency action should not be placed in such a position of finality. In these cases, review should

139. Ibid.

140. 309 U.S. 470 (1940).

141. Davis, supra note 133 , at 779.

142. Federal Communications Commission v. National Broadcasting Co., 319 U.S. 239, 260 (1943).

143. Ibid., quoting from the opinion of the court below.

144. Davis, supra note 133, at 793, referring to Associated Industries v. Icles, 134 F2d 694, 707 (2d Cir. 1943). 
be made available at the suit of the one party who can challenge the administrative action. ${ }^{145}$ As stated by the Court in the Sanders case, "Congress had some purpose in enacting $\S 402$ (b)(2). It may have been of opinion that one likely to be financially injured by the issue of a license would be the only person having a sufficient interest to bring to the attention of the appellate court errors of law in the action of the Commission in granting the license." 146

That Justice Frankfurter often tends to lose sight of the need for making sure that someone can review administrative action is seen even more clearly in his dissent without opinion in the more recent case of Parker $v$. Fleming. ${ }^{147}$ The Court there held that a tenant could obtain review of an order of the Price Administrator authorizing his landlord to begin eviction proceedings, as a person "aggrieved" and "subject to" the order within the meaning of the statutory provision governing standing. ${ }^{148}$ "If these tenants cannot 'protest' this order issued under these regulations," asserted Mr. Justice Black, "no one can; and if they cannot challenge it in the Emergency Court of Appeals, they cannot effectively challenge it at all." 149

The dissenting Justices, of whom Justice Frankfurter was one, found it unnecessary to state the reasons for their disagreement with the Court. As far as Justice Frankfurter is concerned, his dissent here would appear to follow naturally both from his $K O A$ dissent and from his general approach to the question of the availability of review. If he could hold that KOA was not adversely affected by the grant of an application which could result in interference with its broadcasts, he should reach the same result insofar as a tenant subject to immediate eviction would be concerned. Nor would he be deterred by the argument based upon the dangers of administrative finality. As we have already seen, his approach to judicial review does not start with a predilection in favor of the availability of review.

\section{B. SCOPE OF REVIEW}

Law-fact distinction. In view of Justice Frankfurter's respect for administrative expertise and his insistence upon a limited role for the courts, it is not surprising that he has not joined the ranks of those seeking to broaden the scope of review over agency action. "Even when resort to courts can be had to review a Commission's order," reads his first significant administrative law opinion, "the range of issues open to review is narrow. Only questions affecting constitutional power,

145. See Note, 98 U. of PA. L. Rev. 70, 74 (1949).

146. 309 U.S. at 477.

147. 329 U.S. 531, 538 (1947). Vinson, C.J., and Burton, J., also dissented without opinion.

148. 50 U.S.C.A. ApP. $\S \S 923,924$ (Supp. 1950).

149. 329 U.S. at $537-8$. 
statutory authority and the basic prerequisites of proof can be raised. If these legal tests are satisfied, the Commission's order becomes incontestable." 150

As Justice Frankfurter sees it, the courts have nothing to do with the wisdom of challenged administrative action. ${ }^{151}$ As expressed by him in a case where certain regulations were assailed as arbitrary and capricious, "If this contention means that the Regulations are unwise, . . . we can only say that the appellants have selected the wrong forum for such a plea. . . . We certainly have neither technical competence nor legal authority to pronounce upon the wisdom of the course taken by the Commission.' 152 Our duty is at an end when we find that the action of the Commission was based upon findings supported by evidence, and was made pursuant to authority granted by Congress." 153

Justice Frankfurter's approach to the scope of review is based upon the well-known distinction between questions of law and questions of fact. As to the latter, the primary responsibility of decision is with the administrative expert. It is only the former that are to be decided judicially. "If the action rests upon an administrative determinationan exercise of judgment in an area which Congress has entrusted to the agency-of course it must not be set aside because the reviewing court might have made a different determination were it empowered to do so. But if the action is based upon a determination of law as to which the reviewing authority of the courts does come into play, an order may not stand if the agency has misconceived the law." 154

If he has felt that the agency concerned has made an error of law, Justice Frankfurter has not hesitated to set aside its action. Such a case, in his view, was Federal Trade Commission v. Bunte Bros., ${ }^{155}$ where the FTC had issued a cease and desist order against so-called "break and take" sales of candy, which made the amount the purchaser received dependent upon chance. Although the sales took place wholly within the state of Illinois, the Commission urged that its statutory authority to prevent "unfair methods of competition in commerce" included the power to proscribe unfair methods used in intrastate sales when these resulted in a handicap to interstate competitors. The Court rejected this contention. As Justice Frankfurter saw the problem it was solely one of the meaning of the language of the FTC Act, ${ }^{156}$ and the Commission was wrong in its construction. "The

150. Rochester Telephone Corp. v. United States, 307 U.S. 125, 139-40 (1939).

151. Virginia Electric Co. v. National Labor Relations Board, 319 U.S. 533, 546 (1943)

152. Quoting from his own opinion in Board of Trade v. United States, 314 U.S. 534, 548 (1942).

153. National Broadcasting Co. v. United States, 319 U.S. 190, 224 (1943).

154. Securities \& Exchange Commission v. Chenery Corp., 318 U.S. 80,94 (1943). See also Scripps-Foward Radio v. Federal Communications Commission, 316 U.S. 4, 10 (1942).

155. 312 U.S. 349 (1941).

156. $38 \$_{\text {TAT. }} 719$ (1914), 15 U.S.C.A. $\$ 45$ (1941). 
construction of $\S 5$ urged by the Commission would thus give a federal agency pervasive control over myriads of local businesses in matters heretofore traditionally left to local custom or local law. . . . An inroad upon local conditions and local standards of such far-reaching import as is involved here, ought to await a clearer mandate from Congress." 157

The result in the Bunte case follows from Justice Frankfurter's treatment of the question at issue as one of law. The judicial treatment of a particular finding as one of "law" or "fact" is of cardinal importance for purposes of determining the scope of review. If it is treated as one of law, the courts are enabled to exercise a broad reviewing power; if it is treated as one of fact, judicial review is limited by the "substantial evidence" rule. The extent of review thus depends upon which side of the law-fact dividing line the given finding is seen to fall. Yet, as Justice Frankfurter has recognized, there is great difficulty in concrete cases in determining on which side of the line a particular finding falls. The law-fact distinction "is often not an illuminating test and is never self-executing." 158

Statutory Interpretation.-In the Bunte case, Mr. Justice Frankfurter treated the question of construction of section 5 of the FTC Act as one of law. On the other hand, he has asserted, on other occasions, that not all questions involving the interpretation of statutes are to be treated as questions of law for purposes of the scope of review. As stated by him in connection with review of decisions of the Tax Court, 159 "the construction of documents has for historic reasons been deemed to be a question of law in the sense that the meaning is to be given by judges and not by laymen. But this crude division between what is 'law' and what is 'fact' is not relevant to the proper demarcation of functions as between the Tax Court and the reviewing courts. To hold that the Circuit Courts of Appeals, and eventually this Court, must make an independent examination of the meaning of every word of tax legislation, no matter whether the words express accounting, business or other conceptions peculiarly within the special competence of the Tax Court, is to sacrifice the effectiveness of the judicial scheme designed by Congress especially for tax litigation to an abstract

157. Id. at 354. Compare Champlin Rfg. Co. v. United States, 329 U.S. 29, 35 (1946) (dissenting opinion, per Reed, J., joined in by Frankfurter, J.) ; United States v. American Union Transport, 327 U.S. 437, 457 (1946) (dissenting opinion) ; Polish Alliance v. National Labor Relations Board, 322 U.S. 643 (1944); Jersey Central Co. v. Federal Power Commission, 319 U.S. 61, 79 (1943) (dissenting opinion, per Roberts, J., concurred in by Frankfurter, J.).

158. Baumgartner v. United States, 322 U.S. 665, 671 (1944).

159. The scope of review over its decisions being the same as in the casc of other administrative agencies at that time. 
notion of 'law' derived from the merely historic function of courts generally to construe documents, including legislation." Ici

A leading authority on statutory interpretation has divided the steps in the judicial process of interpreting statutes into three parts: (1) finding or choosing the proper statute or statutes applicable; (2) interpreting the statute law in its technical sense; (3) applying the meaning so found to the case at hand. ${ }^{161}$ On the other hand, it has been urged that the interpretation and application of statutes are two different things. In this view, interpretation properly so called includes only the determination of the proper sensible meaning of the statute. Application is the process of determining whether the facts of the particular case are within or without that meaning. ${ }^{162}$

Justice Frankfurter has indicated that he is in accord with the second of these views on the meaning of statutory interpretation, at least insofar as the law-fact classification for purposes of the scope of review is concerned. It is for this reason that he has been such a strong supporter of the doctrine of Dobson v. Commissioner, ${ }^{163}$ where, the "Court made a brave effort . . . to meet some of the difficulties of the present distribution of judicial authority in tax cases by lodging practical finality in a Tax Court decision unless it involves a 'clear-cut mistake of law." "164 The Dobson doctrine left to the specialized equipment of the Tax Court and the trained instinct that came from its experience "the final say ... as to matters which involved construction of legal documents and the application of legislation." 165 In doing so, in Justice Frankfurter's view, it dealt with the practicalities of the situation instead of relying on the "grab-bag concepts of 'law' and 'fact' as a basis of review." 166

160. Trust of Bingham v. Commissioner, 325 U.S. 365, 380 (1945) (concurring opinion).

161. DeSloovère, Steps in the Process of Interpreting Statutes, 10 N.Y.U.L.Q. REv. 1 (1932).

162. Id. at 17.

163. 320 U.S. 489 (1943), opinion per Jackson, J. Justice Frankfurter had anticipated the Dobson doctrine in Helvering v. American Dental Co., 318 U.S. 322, 331 (1943) (dissenting opinion, joined in by Jackson, J.).

164. Burton-Sutton Oil Co. v. Commissioner, 328 U.S. 25, 37 (1946) (concurring opinion).

165. Trust of Bingham v. Commissioner, 325 U.S. 365, 381 (1945) (concurring opinion).

166. Burton-Sutton Oil Co. v. Commissioner, 328 U.S. 25, 37-S (1946). Other cases indicating his adherence to the Dobson doctrine are Commissioner v. Sunnen, 333 U.S. 591, 610 (1948) (dissent) ; Bazley v. Commissioner, 331 U.S. 737, 742 (1947); Commissioner v. Estate of Bedford, 325 U.S. 283, 292 (1945); Commissioner v. Wemyss, 324 U.S. 303, 307 (1945); MrcDonald v. Commissioner, 323 U.S. 57, 64-5 (1944). Section 1141 (a) of the Internal Revenue Code was amended in 1948 so that review of the decisions of the Tax Court now proceeds in the same manner and to the same extent as review of decisions of the federal district courts in civil actions tried without a jury. This changes the rule of the Dobson case, insofar as review of the Tax Court is concerned. 
Justice Frankfurter's views on the question of statutory interpretation have not been limited to the field of tax administration; he has not hesitated to apply them to other administrative law cases. Thus, he was an early adherent of Gray v. Powell ${ }^{167}$ where, as explained by Justice Rutledge in a later case, the Court held that though "undoubtedly questions of statutory interpretation .... are for the courts to resolve. . . . where the question is one of specific application of a broad statutory term in a proceeding in which the agency administering the statute must determine it initially, the reviewing court's function is limited." 168 In such cases, the administrative determ nation is to be accepted if it has warrant in the record and a reasonable basis in law. ${ }^{169}$

Mr. Justice Frankfurter had, in fact, anticipated Gray v. Powell in his opinion in the Rochester Telephone case. ${ }^{170}$ Upholding the finding of the Federal Communications Commission there that Rochester was under the "control" of another company within the meaning of the statute and hence subject to the jurisdiction of the Commission, Justice Frankfurter stated that "this is an issue of fact to be determined by the special circumstances of each case. So long as there is warrant in the record for the judgment of the expert body it must stand." 171

It must be admitted that under the principle of Gray v. Powell, the rule that questions of statutory construction are for the courts on review loses much of its force. This is true even though, strictly speaking, the finding at issue in this type of case involves only the application of a statutory term to a particular state of fact. As Justice Frankfurter has aptly pointed out, "Meaning derives vitality from application. Meaning is easily thwarted or distorted by misapplication." ${ }^{172}$ It can consequently be argued, for example, that the question of who is an "employee" within the meaning of the National Labor Relations Act is a question of the meaning of the Act, and, therefore, is a judicial and not an administrative question. ${ }^{173}$ There are, indeed, some indications in more recent cases that Justice Frankfurter is tending to-

167. 314 U.S. 402 (1941).

168. National Labor Relations Board v. Hearst Publications, 322 U.S. 111, 130 (1944).

169. Id. at 131 .

170. Rochester Telephone Corp. v. United States, 307 U.S. 125 (1939).

171. Id. at 145-6. See Barrett Line v. United States, 326 U.S. 179, 202 (1945) (dissenting opinion per Vinson, C.J., joined in by Frankfurter, J.); United States v. Carolina Carriers Corp., 315 U.S. 475, 490 (1942) (dissenting opinion per Jackson, J., concurred in by Frankfurter, J.), where it was asserted that the majority of the Court had paid only lip service to the principle of Gray v. Powell.

172. Trust of Bingham v. Commissioner, 325 U.S. 365, 380 (1945) (concurring opinion).

173. Paraphrasing Roberts, J., dissenting, in National Labor Relations Board v. Hearst Publications, 322 U.S. 111, 136 (1944). 
ward this point of view. ${ }^{174}$ We do not, however, yet have the benefit of a recent opinion by him indicating whether in fact there has been any shift in his attitude to the Gray v. Powell type of case.

Jurisdictional fact.-The finding at issue in the Gray v. Powell type of case is not only a finding involving a question of statutory interpretation, but is also a finding of "jurisdictional fact" in the sense that its presence is a condition precedent to the lawful exercise of administrative authority. Thus, in Gray v. Pou'ell, the agency power to act was dependent upon the finding that the private party was not a "producer-consumer" within the exemption provisions of the enabling act, ${ }^{175}$ for the statutory price-fixing scheme was not operative in the absence of such a finding. To apply the normal theory of limited review to such a case, it can be argued, would run counter to the general policy of Anglo-American law against allowing inferior tribunals to make a final determination as to their own jurisdiction. "An agency may not finally decide the limits of its statutory power," the Supreme Court has asserted. "That is a judicial function." 170 Where the administrative jurisdiction depends upon a particular finding, the reviewing court should be able to determine for itself whether that finding is correct, even though the finding happens to be one of fact.

Justice Frankfurter has indicated that he is wholly out of sympathy with attempts to secure broad review based upon this "jurisdictional fact" doctrine. As he sees it, "analysis is not furthered by speaking of such findings as 'jurisdictional' and not even when-to adapt a famous phrase-jurisdictional is softened by a quasi. 'Jurisdiction' competes with 'right' as one of the most deceptive of legal pitfalls. The opinions in Crowell v. Benson ${ }^{177}$... a and the casuistries to which they have given rise bear unedifying testimony of the morass into which one is led in working out problems of judicial review over administrative decisions by loose talk about jurisdiction." 178

Constitutional fact.-The doctrine of "constitutional fact" articulated

174. National Labor Relations Board v. Jones \& Laughlin Co., 331 U.S. 416, 431 (1947) (dissent); National Labor Relations Board v. Athins \& Co., 331 U.S. 398, 415 (1947) (dissent); Packard Co. v. National Labor Relations Board, 330 U.S. 485, 501 (1947) (agreement with dissenting opinion of Douglas, J.), cases which involved the same finding as that at issue in National Labor Relations Board v. Hearst Publieations, 322 U.S. 111 (1944). See also Social Security Board v. Nierotko, 327 U.S. 358, 370 (1946) (concurring opinion).

175. Bituritnous Coal Act, 50 Stat. 72 (1937), 26 U.S.C.A. $\$ 3520$ (1940).

176. Social Security Board v. Nierotko, 327 U.S. 358,369 (1946).

177. 285 U.S. 22 (1932), the leading case applying the jurisdictional fact doctrine See Schwartz, Does the Ghost of Crowell v. Benson Still Walk?, 98 U. of PA. L. Rev. 163 (1949).

178. Yonkers v. United States, 320 U.S. 685, 695 (1944) (dissenting opinion). See, similarly, Estep v. United States, 327 U.S. 114, 142 (1946) (concurring opinion). 
in Ohio Valley Water Co. v. Ben Avon Borough ${ }^{170}$ is the logical fulfillment of the "jurisdictional fact" doctrine, for, in this country, the ultimate limits to the lawful exercise of any power are those contained in the organic instrument. Whenever a constitutional issue is raised, said the Court in the Ben Avon case, a fair opportunity must be provided "for submitting that issue to a judicial tribunal for determination upon its own independent judgment as to both law and facts; otherwise the order is void because in conflict with the due process clause." 180 To vest the administrative finding here with finality would be to allow the administrative body itself to find the facts upon which the constitutional exercise of its authority depends.

The doctrine of "constitutional fact" is but the "jurisdictional fact" doctrine in special form. It applies to constitutional limitations on administrative jurisdiction the same reasoning which the doctrine of jurisdictional fact applies to statutory limitations. ${ }^{181}$ In view of Justice Frankfurter's attitude toward the "jurisdictional fact" doctrine, it is not surprising that he has displayed the same hostility toward the doctrine of "constitutional fact".

The "constitutional fact" doctrine has caused the greatest difficulty in its application to the field of utility regulation. In 1930, speaking of the barriers to effective regulation of public utilities, Professor Frankfurter asserted that the "heart of the difficulty is the current judicial approach to utility regulation. Out of the constitutional provision safeguarding property against deprivation 'without due process of law,' the Supreme Court has evolved a doctrine that a utility is entitled to a fair return on its present "value' ". ${ }^{182}$ Under the well-known formula of Smyth v. Ames, ${ }^{183}$ in determining the present value of the utility, account must be taken of the original cost of construction, the amount invested, and the cost to reproduce the property. And, under the Ben Avon doctrine the courts on review must determine for themselves the correctness of the valuation fixed by the agency. Since the constitutional issue of due process is involved, there must be full review of both law and fact.

Justice Frankfurter has strongly objected both to the valuation formula of the Court and to what he has asserted to be unduly broad judicial review in such cases, where the constitutional issue can always be raised. The formula of Smyth $v$. Ames, as he sees it, has met the rebuff of facts. ${ }^{184}$ "No judicial pronouncements upon matters funda-

179. 253 U.S. 287 (1920).

180. Id. at 289.

181. Dickinson, Crowell v. Benson: Judicial Revicze of Administrative Detcrminations of Questions of "Constitutional Fact," 80 U. oF PA. L. REv. 1055, 1072 (1932).

182. Frankfurter, The Public and Its Governatent 101 (1930).

183. 169 U.S. $466,546-7$ (1898).

184. Driscoll v. Edison Co., 307 U.S. 104, 123 (1939) (concurring opinion). 
mentally economic run so counter to the views of economists as do the more recent utterances of the Supreme Court upon present value. They are based upon unrealities, are financially unsound, and lead to uncertainty and speculation." 185

Believing as he did on his elevation to the bench that effective utility regulation was caught in the quicksands of the judicial doctrines of valuation, ${ }^{186}$ Justice Frankfurter took the first occasion presented to object to the "mischievous formula" of Smytlz v. Ames. ${ }^{15 i}$ "The force of reason, confirmed by events, has gradually been rendering that formula moribund by revealing it to be useless as a guide for adjudication." 188 And he went on to deny the need for broad judicial review in these cases. "The determination of utility rates ... does not present questions of an essentially legal nature in the sense that legal education and lawyers' learning afford peculiar competence for their adjustment. These are matters for the application of whatever knowledge economics and finance may bring to the practicalities of business enterprise." 189

Since he has gone this far, it would not be difficult for Justice Frankfurter to take the further step of abandoning broad judicial review over the constitutional elements involved in utility regulation. He has, indeed, come close to taking that step in Railroad Commission of Texas $v$. Rowan $\&$ Nichols Oil Co. ${ }^{130}$ The case involved the validity of an oil proration order of the Commission which was challenged as contrary to the Fourteenth Amendment. Under the Ben Aion doctrine, the validity of the order in such a case was reviewable both as to the law and facts on the independent judgment of the revieving court. But Justice Frankfurter, who delivered the opinion of the Court, treated this as an ordinary case calling for the application of the rule of limited review. "A controversy like this always calls for fresh reminder that courts must not substitute their notions of expediency and fairness for those which have guided the agencies to whom the formulation and execution of policy have been entrusted." 191 The courts must thus accept the agency judgment "even in the face of convincing proof that a different result would have been better." 192 And he implies that this is so even though a constitutional issue has been

185. Frankfurter, The Public and Its Governarent 103 (1930).

186. Id. at 113 .

187. In his concurring opinion in Driscoll v. Edison Co., 307 U.S. 104, 122 (1939).

188. Ibid.

189. Ibid. See, also, on the limited judicial role in rate fixing cases, Board of Trade v. United States, 314 U.S. 534, 546 (1942); United States v. Morgan, 313 U.S. 409, 417 (1941). But compare Federal Power Commission v. Hope Natural Gas Co., 320 U.S. 591, 626-7 (1944) (dissenting opinion).

190. 310 U.S. 573, as amended, 311 U.S. 614 (1940); 311 U.S. 570 (1941).

191. 310 U.S. at $580-81$.

192. Id. at 584 . 
raised. "Certainly in a domain of knowledge still shifting and growing, and in a field where judgment is therefore necessarily beset by the necessity of inferences bordering on conjecture even for those learned in the art, it would be presumptuous for courts, on the basis of conflicting expert testimony, to deem the view of the administrative tribunal . . . offensive to the Fourteenth Amendment." 193

The opinions in the Rowan \& Nichols cases are not very satisfactory insofar as clarifying the present status of the Ben Avon doctrine is concerned. It seems clear, from the analysis in Justice Roberts' dissenting opinion in the first case, ${ }^{194}$ that Justice Frankfurter's opinion announces principles contrary to those established by the Ben Avon case. Yet the Ben Avon doctrine is nowhere directly mentioned by Justice Frankfurter. It is consequently difficult to tell whether the Rowan \& Nichols cases presage a general overruling of Ben Avon or whether they are to be limited to their particular field. The emphasis throughout Justice Frankfurter's opinion is on the need for experlise to solve the peculiar difficulties $0^{\circ}$ proration, which involve even more technical and scientific competence than do valuation cases. ${ }^{106}$ Ben Avon may consequently still have some effect in the field of ratemaking.

\section{CONCLUSION}

Justice Frankfurter is usually thought of as one of the right-wing members of the present Court. But it should be borne in mind that insofar as the field under inquiry is concerned, even so-called conservative members of this Court are far more friendly toward administrative authority than were most of the members of its predecessors. The characterization of a Justice of the present Court as "conservative" does not, therefore, mean that he is hostile toward the administrative process. In his acceptance of the place of administrative expertise and his insistence upon the limitations of judicial control, Justice Frankfurter has typified the attitude of the Justices of this Court. It is true that he has been somewhat more narrow in his views on the availability of review than the rest of the Justices. This has, however, been due primarily to his notions on the restricted competence of courts where jurisdiction has not been expressly conferred upon them by the legislature.

On the other hand, where jurisdiction has been granted to the courts by the Congress, Justice Frankfurter has displayed a tendency to insist that the judicial function is more than a perfunctory one. Thus, in speaking of the judicial enforcement of agency subpoenas, he has stated that "in the discharge of that duty courts act as courts

193. Id. at 581-2. See, similarly, 311 U.S. at 576.

194. 310 U.S. at 584.

195. See Comment, 39 Mrch. L. Rev. 438, 447 (1941). 
and not as administrative adjuncts. The power of Congress to impose on courts the duty of enforcing obedience to an administrative subpoena was sustained precisely because courts were not to be automata carrying out the wishes of the administrative. They were discharging judicial power with all the implications of the judicial function in our constitutional scheme." 196 And, in dealing with the authority given to the courts under a statutory review provision, he held that the power granted carried with it the authority to stay the agency action pending review, as part of the traditional equipment for the administration of justice. Judicial review might be an "idle ceremony" if such authority were not implied. ${ }^{197}$

"How to fit ancient liberties, which have gained a new preciousness, into solution of those exigent and intricate economic problems that have been too long avoided rather than faced, is the special task of Administrative Law," wrote Justice Frankfurter in 1941. ${ }^{195}$ He would be among the first to admit that that task is still, in large measure, with us. Insofar as he is concerned, the problem has, indeed, become a more difficult one. For he has come to realize that abdication of the field to the administrator will not lead to a solution. "It will not do to say that it must all be left to the skill of experts." ${ }^{103}$ The judiciary, too, has a role to play. Justice Frankfurter has thus at least in part reversed his earlier emphasis on the place of administration. "Courts no less than administrative bodies," he stated significantly in the Scripps-Howard case, "are agencies of government. Both are instruments for realizing public purposes." 200

196. Penfield Co. v. Securities \& Exchange Commission, 330 U.S. 585, 604 (1947) (dissenting opinion).

197. Scripps-Howard Radio v. Federal Communications Commission, 316 U.S. 4, 9-10 (1942).

198. Foreword, 41 CoL. L. Rev. 585, 586 (1941).

199. Federal Power Commission v. Hope Natural Gas Co., 320 U.S. 591, 627 (1944) (dissenting opinion).

200. Scripps-Howard Radio v. Federal Communications Commission, 316 U.S. 4, 15 (1942). 